\title{
Performatywność reprezentacji
}

ABSTRACT. Krajewska Anna, Performatywność reprezentacji [The performativity of representation]. "Przestrzenie Teorii" 28. Poznań 2017, Adam Mickiewicz University Press, pp. 7-18. ISSN 1644-6763. DOI 10.14746/pt.2017.28.0.

Starting from a reference to René Magritte`s painting "The Images of Treachery", the introductory article focuses on a performative understanding of representation. Pointing to the perspective of this painting, literary fiction, acting and masks, it refers to dramatic views in literary studies.

KEYWORDS: representation, "performative act" (Wolfgang Iser), "performance of referentiality" (Derek Attridge) "suspensions of perception" (Jonathan Crary), actor, staging

René Magritte w 1929 roku stworzył jeden ze swoich najsłynniejszych obrazów, należący do serii o podobnym temacie, na którym pod namalowaną fajką umieścił słowa: „Ceci n’est pas une pipe” (,To nie jest fajka”). Intrygujące dzieło stało się między innymi pretekstem do rozważań Michela Foucaulta na temat przedstawienia jako rozbijania wyobrażeń o idealnym odwzorowaniu świata słów i rzeczy, a także obserwacji cech pisma nieopozycyjnych wobec rysunku. Dodajmy - przedstawienia (Darstellung - niem. zarówno w znaczeniu inscenizacji, jak i procesu przedstawiania oraz Auffuehrung - niem. w sensie teatralnym jako wystawienia sztuki). Obraz Magritte’a wytworzył „podwójną scenę” (Derridiańską double scene), zacierająca nie tylko granice między rzecza, słowem a obrazem, ale wprowadził też, moim zdaniem, modelową wręcz sytuację „odgrywania referencji” (określenie zastosowane przez Dereka Attridge'a ${ }^{1}$ wobec literatury sprawdza się także w malarstwie). Granie fałszywym podobieństwem obrazu i realistycznych wyobrażeń malarskich ma bogatą tradycję: od Panien dworskich Diega Velázqueza (którego słynne dzieło analizował w kontekście reprezentacji między innymi także Michel Foucault ${ }^{2}$ ), przez takie obrazy jak Bar $w$ Folies-Bergère, W cieplarni, Balkon Édouarda Maneta, Parada cyrkowa, Sklep $i$ dwie postaci Georges'a Seurata czy Sosny i skaty Paula Cèzanne'a (o których wypowiada się Jonathan Crary w książe Zawieszenia percepcji ${ }^{3}$, opi-

${ }^{1}$ D. Attridge, Jednostkowość literatury, przekł. P. Mościcki, Kraków 2007.

${ }^{2}$ M. Foucault, Panny dworskie, [w:] tegoż, Tajemnica Las Meninas. Antologia tekstów, wybór i red. A. Witko, Kraków 2006.

${ }^{3}$ J. Crary, Zawieszenia percepcji. Uwaga, spektakl i kultura nowoczesna, przekład Ł. Zaremba, I. Kurz, red. nauk. i posł. I. Kurz, Warszawa 2009. 
sując historię odstępstw, wyłomów i „rozluźnień” w rozumianym binarnie podobieństwie), po dzieła na przykład Jacksona Pollocka (wiązane często z teorią fraktalnych powtórzeń). W książce Crarego na szczególną uwagę zasługuje fakt, że autor często posługuje się wyobraźnią i językiem opisu dotyczącym spektaklu, teatru, przestrzeni sceny itp., do czego nawiązuje też zawarte w tytule określenie „zawieszenie”, które kojarzyć się może z dramatycznym suspensem, rozumianym jako zawieszenie akcji, stosowane także w prozie. Zasługą Magritte'a jest jednak wprowadzenie do wątku podobieństwa jeszcze większej komplikacji, polegającej na umieszczeniu w samym obrazie napisu zdania interpretującego przedstawiany na obrazie przedmiot (a właściwie dokonującego swego rodzaju jego „wymazania”, słownego unicestwienia). Zakwestionowanie pierwotnego, narzucającego się z całą oczywistością odczytania obrazu sprawia, że odbiorca doprowadzony jest do stanu konfuzji: oto absurd logiczny: fajka $\wedge \sim$ fajka. Pozostaje ślad fajki, zaczyna się gra w definiowanie podobieństwa. Obraz kłamie słowu, a słowo oczom kłamie. „Myśl z duszy” wcale nie „leci bystro”, łamie się nie tylko w słowach, łamie się już na granicy obrazu (aktu pikturalnego) i pisma (aktu słownego), pokazując ich możliwe interferencje i utożsamienia. Dzieło sztuki staje się rodzajem, jak chciałabym nazwać zjawisko, dramatografii ${ }^{4}$. Widz nie tylko wchodzi na scenę obrazu, ale równocześnie znajduje się na scenie pisma, uczestniczy w procesie oglądania i czytania. Poza tym jeszcze dodatkowo, w tym samym momencie dokonuje sprzecznych interpretacji wyników czytania i skutków oglądania (uprawia jednocześnie lekturę dramatu obrazu i dramatu pisma). Obserwowanie działania słów prezentowanych na scenie teatru-obrazu, prowadząc do sprzecznych konkluzji, równocześnie każe akceptować i jedno, i drugie rozwiązanie - obecność i nieobecność fajki. Ale też sugeruje łączność linii rysunku fajki i linii rysunku odręcznego pisma. Jesteśmy świadkami procesu wytwarzania reprezentacji jako aktu performatywnego. Dodajmy dla ścisłości - nie chodzi o „teatr w obrazie” ani o „pismo w obrazie”, ale o utworzenie dramatografii, czyli „pisania dramatu obrazu". Obraz nie jest oknem wychodzącym na rzeczywistość ani lustrem odbijającym świat. Raczej już jest sceną rysunku: kształtu przedmiotu i kroju pisma. Jest obrazem świata równocześnie wymazującym świat. Zatem, czy zatrzymuje się i wyczerpuje w swoim własnym estetycznym wymiarze, czy może otwiera na rzeczywistość, taką jaką zna odbiorca, który współtworzy obraz poprzez swoje doświadczenia intelektualne, kulturowe, zmysłowe? Możemy zatem oglądać swoistą dramaturgię obrazu i pisma, wciagająca odbiorcę w proces równoczesnego powoływania i zaprzeczania rzeczywistości. Gdyby zapytać, jak czynił to William John Thomas Mitchell,

${ }^{4}$ A. Krajewska, Dramatografia, „Przestrzenie Teorii” 2017, nr 27, s. 195-226. 
„czego chcą obrazy?”5, odpowiedź byłaby aporią fikcji i realności. Bardzo podobnie postępował Derrida, gdy w Prawdzie w malarstwie interpretował słowa Paula Cézanne'a, wyrażające przyrzeczenie powiedzenia prawdy w malarstwie, jako akt performatywny, mogący być zarówno działaniem malarskim, jak i wypowiedzią słowna.

Czym jest zatem „prawda” w sztuce pisma i obrazu, w jaki sposób kształtuje pojęcie reprezentacji? Adam Dziadek, analizując typograficzne dzieła Stefana Themersona, bardzo słusznie stwierdza,

że nigdy nie chodziło w nich o ,jakieś intersemiotyczne gry”, o nic takiego, co można by uznać za prosta wymianę znaków dokonująca się między systemami [...]. Mówiąc „gry intersemiotyczne”, z góry zakłada się odrębność systemów znaczenia, a w książkach Themersona idzie przede wszystkim o ich koegzystencję, współistnienie. Stronice tych ksiazzek sa, by tak rzec, pages performatives, stronicami pisania i/lub czytania, swoistym dramatem znaczenia [wyróżn. A.K.], w którym poszczególne sceny [wyróżn. A.K.] rozgrywają się symultanicznie ${ }^{6}$.

Dodajmy - czytanie, pisanie, malowanie stają się nieopozycyjne i w tym akcie współtworzenia sztuki dochodzimy do specyfiki dramaturgii odbioru jako dramaturgii performatywnej, która pozwala na odbiór anamorficzny (widzimy fajkę i widzimy słowa): oglądamy obraz i czytamy tekst, ale też patrzymy z dystansu i równocześnie obserwujemy działanie „odgrywania” procesu reprezentacji. Reprezentacja przestaje być prostą relacją podobieństwa, staje się wytwarzanym procesem performatywnym, w którym nie ma jednoznacznych rozstrzygnięć.

$$
* * *
$$

Chciałoby się teraz z kolei powiedzieć, parafrazując Magritte'a: „To nie jest zwierciadło”. Wraz z załamaniem się wszelkich „metafor umysłu” określających stosunek sztuki, a zwłaszcza malarstwa i literatury, do świata, takich jak: „zwierciadło”, tabula rasa, camera obscura „okno”, „szyba” itp. ${ }^{7}$ lub „szklana istota” [glassy essence ${ }^{8}$ ] (określić je można mianem zwierciadlanych) i zastapienia ich tymi, które kładą akcent na aktywność samego umysłu w tworzeniu obrazu świata - zwłaszcza związanych z metaforami oczu, wzroku, ale także lampy czy płomienia świecy - (rzec by można: wzrokowymi), nastapił etap trzeci - obserwacji samego procesu pracy umysłu

${ }^{5}$ W.J.T. Mitchell, Czego chca obrazy? Pragnienia przedstawień, życie i miłości obrazów, przeł. Ł. Zaremba, Warszawa 2015.

${ }^{6}$ A. Dziadek, Themerson i Schwitters, „Teksty Drugie” 2006, nr 4, s. 91.

${ }^{7}$ M.H. Abrams, Zwierciadto i lampa. Romantyczna teoria poezji a tradycja krytycznoliteracka, przeł. M.B. Fedewicz, Gdańsk 2003, s. 68-69.

${ }^{8}$ R. Rorty, Filozofia a zwierciadto natury, tłum. M. Szczubiałka, Warszawa 1994.

$9 \quad$ Performatywność reprezentacji 
(i zmysłów!) w akcie kreacji świata (nazwałabym go etapem performatywnej sceny). Zwierciadła nie przechadzają się już po gościńcu, raczej ustawiły się tak, że w nieskończoność odbijają swoje własne odbicia. Streszczając myśli Richarda Rorty'ego, Michał Paweł Markowski pisze:

Filozofia $i$ zwierciadło natury jest gwałtownym atakiem na epistemologię. W tradycji nadzorowanej przez epistemologię, pisze Rorty, wiedza jest zbiorem adekwatnych przedstawień. [...] umysł obcuje ze swymi przedmiotami w sposób czysty, niezapośredniczony, że widzi ich „szklaną istotę [glassy essence]” i że jego zadaniem jest kolekcjonowanie obiektów wiedzy, które na scenie umysłu [wyróżn. A.K.] pojawiają się niejako same z siebie, w sposób jasny i zrozumiały. Ta zrozumiałość zagwarantowana jest ustaleniem „właściwej” relacji między słowami i rzeczami. To, co w taki czysty sposób nie pojawia się umysłowi, zostaje wyrzucone poza obręb wiedzy jako coś brudnego, zagmatwanego i w konsekwencji fałszywego. Wiedza $\mathrm{w}$ tradycji epistemologicznej jest inscenizacją przejrzystości [wyróżn. A.K.]. To paradoksalne wyrażenie zwraca uwagę na wewnętrzną sprzeczność epistemologicznego projektu, gdzie spotykają się dwie niezgodne tendencje: widzieć rzeczy takimi, jakimi sa [...] i to widzenie konstruować, być jednocześnie bierną i czynną stroną spektaklu [wyróżn. A.K.] ${ }^{9}$.

Przezwyciężając zatem leżący u podstaw epistemologii dualizm - pisze dalej Markowski - Rorty przyjmuje stanowisko zakładające, że „Wiedza nie jest efektem przykładania naszych pojęć (i słów) do rzeczy i sprawdzania stopnia przylegania, lecz praktyką społeczną"10 i dalej rozważa znaczenie Rorty'ańskiej konwersacji wobec przedawnionej idei seminarium (nieaktualnej w sensie utożsamiania jej z kumulacją i gromadzeniem wiedzy zmierzającym do osiagnięcia zgodności, a nie nowoczesną wizją nauki jako pola wymiany myśli, procesu współmyślenia, akceptacji zaskoczeń, nieoczywistości, wahania, nawet za cenę braku uzgodnienia pewności).

Ten długi cytat ujawnia dramaturgię myśli Rorty’ego, ale rodzi też skojarzenia literackie (zwłaszcza ze sztukami lustrzanymi Samuela Becketta ${ }^{11}$ ) oraz licznymi wierszami Tadeusza Różewicza (na przykład słynny nakaz postawiony sobie, by spróbować „opisać twarz z pamięci, nie z lustra”, albo sytuacja patrzenia przez brudna szybę w poczekalni opisana w wierszu Zwierciadto z tomiku Regio: „rzeczywistość/ którą oglądałem/ przez/ brudną szybę/ w poczekalni”). „Brudna szyba”, zwykle interpretowana poprzez

${ }^{9}$ M.P. Markowski, Polityka wrażliwości. Wprowadzenie do humanistyki, Kraków 2013, s. 380.

${ }^{10}$ Tamże, s. 380.

${ }^{11}$ Przywołując terminologię stosowaną przez Rortego glassy essence oraz określenie Richarda Begama mirror play, pisałam o dramatach lustrzanych Becketta: A. Krajewska, Dramaty lustrzane, [w:] Dwudziestowieczna ikonosfera w literaturach europejskich. Wizualizacja $w$ literaturze, pod red. B. Tokarz, Katowice 2002. 
zderzenie z cytatem ze św. Pawła „teraz widzimy niejasno, przez zwierciadło (w zamgleniu/zabrudzeniu), lecz później twarzą w twarz", uzyskuje w wierszu Różewicza jeszcze dodatkowy wymiar polemiki filozoficznej sprowadzającej się do pytania o (nie)możliwość dotarcia do istoty rzeczy, a także o akt odrzucania tego, co w charakterystyce ujęcia wiedzy w tradycji epistemologicznej określane jest przez Rorty'ego jako „nieprzejrzyste”, uznane za coś „brudnego, zagmatwanego i w konsekwencji fałszywego”, które zostaje wyrzucone poza obręb wiedzy pewnej. A może to właśnie niejasne, „zabrudzone”, mętne interesowało najbardziej nie tylko Różewicza, ale i Gombrowicza ${ }^{12}$, i wielu innych współczesnych pisarzy...

Wszystkie zapośredniczenia, jak w ujęciu Rorty`ego praktyka społeczna, sprowadzają sens wiedzy do jej użycia. Więc może jest i etap czwarty - świadomego „odgrywania referencji” do używania, wykorzystywania, kreowania tego procesu w celach osiagnięcia korzyści ideologicznych, aby było tak, jak chcemy, by się świat jawił Innym. Określenie Attridge’a „odgrywanie referencji”, odnoszące się do literatury, może mieć charakter etycznie neutralny, jako uzgadniane pewnej wersji stwarzanego w naszym dyskursie świata, ale może też wykraczać poza sztukę i wkraczać w samą rzeczywistość odbiorcy, kształtując jej obraz w określony, wybrany przez nas sposób. Nasz dyskurs o świecie (jako świadomie fikcyjna konstrukcja) ma opowiedzieć świat w określony sposób, tak, by proponowana dramaturgia przekazu uznana została za „wierne” przedstawienie „rzeczywistości”. Fikcja, traktowana jako „umowa złej wiary”, w sztuce wzbogaca; fikcja jako sterowana ideologią kreacja rzeczywistości deformuje świat, w którym żyje poznajacy podmiot. Wytwarzanie fikcji wspólne jest literaturze i ideologii.

$$
* * *
$$

A gdyby tak jeszcze raz odwołać się do Magritte’a, parafraza tytułu jego obrazu mogłaby teraz brzmieć: „To nie jest fikcja”.

Polskie literaturoznawstwo w małym stopniu podąża dramatycznym tropem. Dlatego dziwi fakt, że - choć pojęcie mimesis ma dramatyczną naturę (przedstawienie) - tak mało w polskim literaturoznawstwie jest odwołań do dramatu, aktorstwa, sceny w pracach dotyczących reprezentacji. Ma rację Danuta Ulicka, pisząc w tekście zamieszczonym w bieżącym numerze „Przestrzeni Teorii”, że:

Większość ujęć, od najwcześniejszych do najnowszych, wychodziła od prozy i na jej materiale konstruowała rozwiązania ogólne. Zdecydowanie rzadziej kwestia

${ }^{12}$ Por. M.P. Markowski, Czarny nurt. Gombrowicz, świat, literatura, Kraków 2004. 
referencji była podejmowana w związku z poezją (Sławiński, 1965; Ziomek, 1975; Kopczyńska i in., 1969; Barańczak, [1983], 1990; Bogalecki, 2011) i dramatem (Ziomek, 1980) ${ }^{13}$.

Dramatem przy okazji problemów reprezentacji nie zajmowano się w Polsce prawie wcale ${ }^{14}$. Jeśli więc pojawiają się nieliczne terminy, przywoływane sa pojęcia z teorii dramatu, to raczej sporadycznie, bez głębszych konsekwencji, albo przy okazji tłumaczenia prac z języków obcych jako zapożyczenia (bardziej terminologiczne niż mające konsekwencje merytoryczne). Porównać warto stopień teatralności w pracach na przykład Wolfganga Isera ${ }^{15}$ : „,taged discourse”, „play”, „,taging”, „performative”. Nie dziwią też poczynione w kontekście referencji bardzo trafne rozpoznania Ulickiej dotyczące podkreślania w rodzimym literaturoznawstwie stałego zestawienia binarnego: życia i literatury (wynikającego zapewne z naszej historii i jej dylematów).

Przyglądając się nielicznym wypowiedziom niektórych badaczy mimesis, jak na przykład Zofii Mitosek, zwłaszcza w artykule „Mimesis”- między udawaniem a referencja, można je zinterpretować na sposób dramatyczny (analizy autorki, kierowane ku podjęciu ruchu kolejnych ustaleń i zawieszeń, noszą znamiona dramatyczności ${ }^{16}$ : [mimesis] „grając na naszych przedstawieniach, wprowadzając nas w stan iluzji, wahania i bezradności, udając i produkując symulakry, poprzez swoją grę zakłóca utarty porządek rzeczy na korzyść niekończącego się poznania - także poznania samej mimesis").

W roku 2007 w artykule Perspektywy performatywizmu Anna Zeidler-Janiszewska pisała w skromnym przypisie „Nie zajmę się też zastosowaniami perspektywy performatywistycznej w literaturoznawstwie (w szczególności antropologicznie zorientowana koncepcja Wolfganga Isera wymaga, moim zdaniem, pilnej kulturoznawczej lektury)"17.

W polskim literaturoznawstwie linię Isera, w kontekście interesujących nas tu tematów, przywoływała szerzej w 2001 roku Anna Łebkowska w związku z zagadnieniem fikcji literackiej, pisząc przede wszystkim o tym

${ }^{13}$ D. Ulicka, Między światami. Rzeczywistość $w$ literaturze - literatura w rzeczywistości rzeczywistość literatury, „Przestrzenie Teorii” 2017, nr 28, s. 23.

${ }^{14}$ Por. Performatywność reprezentacji. Widzialne/niewidzialne, red. K. Czerska, J. Jopek, A. Sieroń, Kraków 2013.

${ }^{15}$ W. Iser, Representation: a performative act, [w:] The Aims of Representation: Subject/ Text/History, ed. by M. Krieger, Stanford 1987.

${ }^{16}$ Por. Z. Mitosek, „Mimesis”- między mimesis a referencja, „Przestrzenie Teorii” 2002, nr 1, s. 46.

${ }^{17}$ A. Zeidler-Janiszewska, Perspektywy performatywizmu, „Teksty Drugie” 2007, nr 5, s. 35 (przypis 1). 
„na czym polega jej rola wobec innych procedur światotwórczych”18. W znamiennie zatytułowanym rozdziale „Kameleon poznania” czy katalizator wyobraźni pisała:

Iser odrzuca - co można by już potraktować jako signum temporis - opozycję: fikcjonalne-rzeczywiste [...] interesuja go mianowicie główne filtry (kultury, estetyki, filozofii), poprzez które opozycja ta była uwidaczniana [...]. Cały wysiłek badawczy skupia się tu na [...] przezwyciężeniu opozycji fakt-fikcja, na odsunięciu daniny spłacanej epistemologii i wreszcie na próbie przesunięcia teorii fikcji na obszar antropologii, co według Isera miałoby się dokonać dzięki zaproponowanej przezeń procedurze pozwalającej uchwycić nie opozycję, ale kontinuum łączące to, co fikcjonalne, z tym, co realne ${ }^{19}$.

W 2006 roku Michał Paweł Markowski wrócił do koncepcji Isera, podejmując problem reprezentacji ${ }^{20}$. W swojej pracy zarysował dwie główne linie myślenia o reprezentacji, pisząc o dwóch postawach, „Auerbachowskiej, zrównującej reprezentacje z mimesis, oraz Iserowskiej, traktującej reprezentację jako akt performatywny" ${ }^{21}$. Wybierzmy zatem propozycję Wolfganga Isera i spróbujmy iść tą droga, myśląc o roli aktora w świetle badań performatywnych.

$\mathrm{W}$ polskich badaniach nad reprezentacja, moim zdaniem, nie została dostatecznie „wygrana” (czyli nie do końca rozegrana i równocześnie nie w pełni zwycięska) linia ujmowania reprezentacji jako procesu performatywnego (linii prowadzącej od fenomenologii Romana Ingardena przez prace Wolfganga Isera, po Jacques'a Derridę, Paula de Mana czy Josepha Hillisa Millera). Performatyka widziana była blisko dekonstrukcji (Anna Burzyńska ${ }^{22}$ ), ale także, co może budzić odruch sprzeciwu, rodzić różne wattpliwości, ma odniesienia do fenomenologii. W podobnym duchu, łącząc miejscami perspektywę performatywności i fenomenologię, interpretuje dzieło Romana Ingardena w tezach artykułów prezentowanych w numerze Jacek Wachowski ${ }^{23}$. Kluczowym punktem zbornym sa jednak, jak się wydaje, liczne prace Isera (czekające na polską recepcję literaturoznawcza), zwłaszcza w jego ujęciu odwołującym się do zacierania granic realności i fikcji i związków z performatyka. Niczego

${ }^{18}$ A. Łebkowska, Między teoriami a fikcja literacka, Kraków 2001 [tu zwłaszcza rozdział: „Kameleon poznania” czy katalizator wyobraźni (teoria Wolfganga Isera), s. 158-184], s. 86.

${ }^{19}$ Tamże, s. $160-162$.

${ }^{20}$ Por. M.P. Markowski O reprezentacji, [w:] Kulturowa teoria literatury, red. M.P. Markowski, R. Nycz, Kraków 2006, s. 330.

${ }^{21}$ Tamże, s. 289.

${ }^{22}$ Por. A. Burzyńska, Dekonstrukcja, polityka i performatyka, Kraków 2013.

${ }^{23}$ Por. J. Wachowski, O odbiorze dzieła literackiego, „Przestrzenie Teorii” 2017, nr 28, s. $95-107$. 
się tu nie przedstawia, nie wymienia, nie podstawia, nie wystawia. Performatywność reprezentacji polegałaby nie tyle na „odgrywaniu referencji”, ile na pokazywaniu aktu tworzenia świata, który równocześnie jest i nie jest prawdziwy, który istnieje równocześnie jako prawdziwy i nieprawdziwy.

$$
* * *
$$

Zatem, parafrazując Magritte'a raz jeszcze, powiedzmy: „To nie jest maska". Od myślenia w kategoriach odwzorowania bardzo trudno się wyzwolić. Pojęcie reprezentacji ma w sobie wpisana, nieubłaganie narzucająca się, binarność; oto jest dane coś (świat, rzeczywistość, przedmiot, zjawisko, człowiek...) i to, co je reprezentuje (znak, symbol, gest, literatura, sztuka...). Naiwnie proste rozróżnienie tkwi przecież już w języku, na przykład gdy mówimy, że ktoś reprezentuje nas w sądzie (pełnomocnik), że ktoś odbiera nagrodę podczas nieobecności laureata (reprezentant), gdy ktoś pełni w zastępstwie moją funkcję, wykonując moje dyspozycje (pełniący obowiązki na moim stanowisku, zastępca) itp. Inny nie jest mna, inny jest zamiast mnie, jedynie tylko mówi i działa w moim imieniu. Ja i on jesteśmy różni, zachowujemy odrębność. Nikt nie pomyli mnie z tym, który mnie reprezentuje. Ale z drugiej strony jesteśmy w jakiś sposób związani, ten, który mnie reprezentuje, zaciera swoją tożsamość po to, by oddać moje intencje, przywołać mój obraz, przekazać moje słowa, wypełnić moją wolę, sam pozostając jednak przezroczystym. Reprezentować znaczy tu prezentować, przedstawiać, ujawniać, uobecniać. Poprzez kogoś zjawiam się jednak ja. Już ten prosty, szkolny przykład pokazuje, że binarność wpisana w pojęcie reprezentacji okazuje się od samego początku pozorna. Czy zatem reprezentantem kogoś mógłby w przyszłości być jego klon (tragizm bycia innym, będąc soba), a może jest nim sobowtór (wytwarzane podobieństwo w określonym celu, na przykład sobowtór władcy), symulant (udawanie tak sugestywne, że czasem wytwarzające poczucie rzeczywistej, odczuwalnej, niedyspozycji), czy szaleniec (choroba polegająca na całkowitym utożsamieniu siebie z innym)? Sprawa komplikuje się jeszcze bardziej, gdy rzecz dotyczy aktora, który jest pośrednikiem między światem uznanym za realny a fikcja. Jaki jest zatem status aktora? I znów upada pozorne odczucie binarności: aktor w perspektywie przygotowywanej roli odtwarza (i tu pojawia się wahanie), czy może raczej stwarza postać. Jest przecież także odwrotnie - to postać wpływa na widzenie aktora (co bowiem znaczy „był wspaniałym Hamletem”?), to suma zagranych ról określa, buduje emploi aktora. A co się dzieje, gdy aktor gra znana z historii postać niefikcyjną? A jeśli został obsadzony w roli postaci niebędącej człowiekiem? A jeśli gra Judasza, Chrystusa, Maryję? A jeśli gra postać fikcyjną która jest aktorem grającym inną rolę? A jeśli aktor 
zechciałby zagrać siebie samego? Czym jest deixis w przypadku aktora, co znaczy „ja”, gdy mówi to aktor? Kluczem do pojęcia reprezentacji jest, moim zdaniem, aktorstwo. Problem jednak polega na przyjmowaniu różnych koncepcji zarówno aktorstwa, jak i reprezentacji.

Przywołując podział Markowskiego dotyczący reprezentacji, próbować można, w drodze myślowego eksperymentu, „dopasować”, przypisać czterem proponowanym przez autora modelom ideologii reprezentacji: epistemologicznemu, ontologicznemu, apofatycznemu i estetycznemu, idei aktorstwa. Z pozoru zadanie będzie łatwe: modelowi epistemologicznemu odpowiadać będzie na przykład naturalistyczna wizja zawarta w systemie Konstantego Stanisławskiego (aktor przedstawia postać, ale, z drugiej strony, dociera do niej poprzez wyposażanie jej w swoje własne doświadczenia przetransponowane dzięki mechanizmom aktorstwa w sztukę), ontologicznemu - średniowieczne uobecnienie (aktor powoduje obecność bytu prawdziwego, aktor umożliwia zjawienie się rzeczywistej postaci, ale, patrząc inaczej, możliwe jest, by Chrystusa niosacego krzyż grało wymiennie wielu aktorów...), apofatycznemu $-\mathrm{z}$ jednej strony zakaz teatru na przykład w kulturach arabskich, jako konsekwencja zakazu przedstawiania - z drugiej teatr jako proliferacja, symulacja na przykład w teatrze absurdu (pokazująca nieprzystawalność rzeczywistości i reprezentacji, ale znów znajdujemy zaprzeczenie, ponieważ równocześnie w wielu sztukach na przykład Becketta czy Ionesco ujawniał się ogromny wpływ myśli religii Wschodu, zwłaszcza buddyzmu, prowadzący do interpretacji dokonanych na przykład przez Thomasa Mertona czy Paula Fostera, skłaniających się w tym przypadku ku orientacji ontologicznej...), i w końcu estetycznemu - rzeczywistość groteskowa, zdeformowana wcale nie zostaje „podstawiona” zamiast realnej, nawet w teatralnych koncepcjach Wielkiej Reformy, tak daleko wypierającej się realności, jak w programie nadmarionety Craiga (gdzie nawet tu trudno jednak mówić o „pustej reprezentacji”; reprezentacja nie jest pusta, ponieważ „teatr bez świata”, jak kiedyś określiłam zjawisko, tak i „teatr bez aktora” jest możliwy tylko wtedy, gdy istnieje „pamięć świata” (tworzona jako hipoteza i weryfikowana nieustannie w odniesieniach zarówno do naszego doświadczenia pamięci realnych ludzi i zdarzeń, jak i kształtów rzeczywistości budowanej w sztuce, obrazów konkretnych postaci, dzieł, typów teatrów, przedstawień utrwalających „wgląd” w wyobrażoną materię świata, powtórzmy materię weryfikowaną stale poprzez naszą praktykę życiowa, społeczna, kulturowa).

Historyczne konwencje i kulturowe odmienności w rozumieniu aktorstwa sprawiały, że myślenie o nim, pojęte jako różnica, dawało się jeszcze przypisać, przyporządkować proponowanym podziałom (nie bez zaprzeczeń, wątpliwości, komplikacji). Im bliżej jednak współczesnej świadomości tych modeli, tym bardziej dominują chęci gry na wszystkich instrumentach rów- 
nocześnie. Performatywność aktorstwa polega na wprowadzaniu publiczności w stan konfuzji, niepewności, odbioru anamorficznego itp. Jeśli wierzysz w jeden model ideologii reprezentacji, musisz być otwarty/a na inne, bo inaczej... (przypomina się nakaz Joe McKenzy'ego: „performuj albo...”). Ta różnorodność to dla Markowskiego kwestia wyboru, ale dla performatyka (czy nie jest to już piąty model ideologii reprezentacji?) traktowana być może jako kwestia wytwarzania (sztuka, zależna od odbioru, wytwarza zmienne, równocześnie możliwe modele reprezentacji). Aktorstwo jest w reprezentacji rozumianej jako akt performatywny elementem koniecznym. Umożliwia zawsze parabazę, element dystansu, „zawieszenia” percepcji, przerwania, „nacięcia” lub przemieszczenia. Pole możliwości, na którym rozgrywa się dramaturgia reprezentacji, jest przestrzenia, w której dokonują się serie kolejnych ustanowień. Sztuka ani nie odbija rzeczywistości, ani nie zostaje podstawiona zamiast niej. Sztuka jest pewną forma ,wykonania”, „powołania” rzeczywistości. Sztuka inscenizuje rzeczywistość, tworzy jej zmienne ideologie, formy, obrazy. Sztuka, sprzężona z natura, człowiekiem i technika, wytwarza rzeczywistości, które bywaja jej przedłużeniem: odgłosem, pogłosem, echem, powidokiem, odblaskiem, co zwrotnie, równocześnie sprawia, że to świat okazuje się odgłosem, pogłosem, echem, powidokiem, odblaskiem sztuki. Sztuka, tak samo jak widzenie, nauka, kultura, nie oznacza rejestrowania, ale jest aktem ustanawiania rzeczywistości, która ma wpływ na nasze sposoby jej ustanawiania. To aktor żongluje różnymi modelami reprezentacji, wytwarza iluzje przedstawiania, uobecniania, odstawienia czy podstawienia.

Zatem czy reprezentacja to problem persony? Maska w różnych kulturach zakrywa, podstawia, wystawia, uobecnia. To też wszystko zależy od przyjętych założeń kulturowych, rytualnych, społecznych itp.

Maska w kulturach zachodnich zakrywała, nadawała umowny charakter, była stabilna (oznaczała typowość - maska komiczna, tragiczna...). Potem zrastała się z twarza, uprzytamniała, że maska jest jedyna twarza. Co zatem „czyni” maska? Maska jest martwa i żywa jednocześnie. Problem maski na pierwszy „rzut oka” jest problemem dualizmu, w istocie w prostej linii jemu zaprzecza. Parafrazując pytanie Mitchella, spytajmy teraz: „czego chce od nas maska"? Performatywna interpretacja maski kieruje nas ku japońskiemu teatrowi nō. Jest czymś (kimś?) narzucającym nam swoje istnienie, przekształcającym nas, zmieniającym nas w coś innego, pozwalająca widzieć siebie od zewnątrz.

$$
* * *
$$

Poetyka tekstu, będącego wstępem do numeru, prowokuje do tego, by kolejny raz zainspirowani Magritte'em powiedzieć - „To nie jest wstęp”. 
Byłoby to jednak z jednej strony asekuracyjne wyznanie, rodzaj usprawiedliwienia wobec braku możliwości wyczerpania odwiecznego, dogłębnie zbadanego, choć stale odsłaniającego nowe oblicza, problemu reprezentacji, ale i z drugiej strony - prowokacyjne pytanie: czy tekst majacy charakter wstępu jest reprezentacją numeru (przedstawia go, uobecnia jego problematykę, występuje w jego imieniu, przyrzeka opowieść o nim, buduje scenę zapowiadając wejście na nią głównych bohaterów: autorów tekstów, którzy za chwilę będą już mówić swoim pełnym głosem)? Czy wstęp jest ramą passe-partout, parergonem? Czy zatem wstęp jest reprezentacją w znaczeniu aktu performatywnego?

W bieżącym numerze „Przestrzeni Teorii” reprezentacja staje się nurtem dominującym, widocznym, nazwanym wprost, ale też spaja różne teksty, przebiegając podskórnie, ujawniając odmienne podejścia do świata, natury, kultury, sztuki wyrażane w odrębnych metodologiach. Danuta Ulicka, wychodząc od pojęcia referencji (którą uznaje za najważniejszy temat zarówno w badaniach literackich, jak i w literaturze i sztuce) w swoim, z pozoru tylko historycznym „przeglądzie” polskiego nowoczesnego literaturoznawstwa, buduje w istocie wypowiedź na temat sposobu pojmowania i pisania historii dyscypliny, jaka jest teoria literatury. Pozostałe teksty, proponując ujęcia dające szansę na odkrywanie nowoczesnego podejścia do świata nauki, sztuki, natury, w nieoczekiwany sposób korespondują z myśleniem o teorii jako o widzeniu problemu kreacji i re-kreacji (gra słów celowo łączy: powtórne stwarzanie i... odpoczynek; odpoczynek od mówienia o metodologiach, zwrotach, szkołach badawczych). Teoria staje się dyscypliną bliską sztuce widzenia: podejmowania intrygujących tematów, dostrzegania wspólnych problemów, proponowania indywidualnych rozwiązań. Zapytajmy zatem w trakcie lektury przedstawionych tekstów, jak czynił to W.J.T. Mitchell wobec obrazów, „czego chce od nas teoria?”. A może raz jeszcze przekornie powiedzmy, parafrazując słynne zdanie z obrazu przedstawienia fajki René Magritte'a, „to nie jest teoria”...

Zamiast streszczać i przywoływać sądy autorów, pozwólmy im już jednak wyjść na scenę pisma i przemówić własnymi słowami.

Anna Krajewska

\section{BIBLIOGRAFIA}

Abrams M.H., Zwierciadto i lampa. Romantyczna teoria poezji a tradycja krytycznoliteracka, przeł. M.B. Fedewicz, Gdańsk 2003.

Attridge D., Jednostkowość literatury, przekł. P. Mościcki, Kraków 2007.

Burzyńska A., Dekonstrukcja, polityka i performatyka, Kraków 2013. 
Crary J., Zawieszenia percepcji. Uwaga, spektakl i kultura nowoczesna, przekł. Ł. Zaremba, I. Kurz, red. nauk. i posł. I. Kurz, Warszawa 2009.

Dziadek A., Themerson i Schwitters, „Teksty Drugie” 2006, nr 4.

Foucault M., Panny dworskie, [w:] M. Foucault, Tajemnica Las Meninas, przekł. A. Tatarkiewicz. Antologia tekstów, wybór i red. A. Witko, Kraków 2006.

Iser W., Representation: a performative act, [w:] The Aims of Representation: Subject/ Text/History, ed. by M. Krieger, Stanford 1987.

Krajewska A., Dramatografia, „Przestrzenie Teorii” 2017, nr 27, s. 195-226.

Krajewska A., Dramaty lustrzane, [w:] Dwudziestowieczna ikonosfera w literaturach europejskich. Wizualizacja w literaturze, pod red. B. Tokarz, Katowice 2002.

Łebkowska A., Między teoriami a fikcja literacka, Kraków 2001.

Markowski M.P., Czarny nurt. Gombrowicz, świat, literatura, Kraków 2004.

Markowski M.P., Polityka wrażliwości. Wprowadzenie do humanistyki, Kraków 2013.

Markowski M.P., O reprezentacji, [w:] Kulturowa teoria literatury, red. M.P. Markowski, R. Nycz, Kraków 2006.

Mitchell W.J.T., Czego chcq obrazy? Pragnienia przedstawień, życie i miłości obrazów, przeł. Ł. Zaremba, Warszawa 2015.

Mitosek Z., „Mimesis”- między udawaniem a referencja, „Przestrzenie Teorii” 2002, nr 1. Performatywność reprezentacji. Widzialne/niewidzialne, red. K. Czerska, J. Jopek, A. Sieroń, Kraków 2013.

Rorty R., Filozofia a zwierciadto natury, tłum. M. Szczubiałka, Warszawa 1994.

Ulicka D., Między światami. Rzeczywistość w literaturze - literatura w rzeczywistościrzeczywistość literatury, „Przestrzenie Teorii” 2017, nr 28, s. 21-75.

Wachowski J., O odbiorze dzieła literackiego, „Przestrzenie Teorii” 2017, nr 28, s. 95-107.

Zeidler-Janiszewska A., Perspektywy performatywizmu, „Teksty Drugie”2007, nr 5, s. 34-47. 
